[Regular Paper]

\title{
Structural Analysis of Petroleum Deasphalted Oils and Their Thermal Cracking Properties
}

\author{
Wega Trisunaryanti, Masahiro Miura, and Masakatsu Nomura* \\ Dept. of Applied Chemistry, Faculty of Engineering, Osaka University, \\ 2-1 Yamadaoka, Suita, Osaka 565
}

(Received May 1, 1995)

\begin{abstract}
To provide an insight into the relation between structural characteristics of petroleum heavy oils and their thermal cracking properties, structural analysis of three kinds of deasphalted oils (DAO) by chromatographic separation, followed by ${ }^{1} \mathrm{H}$ and ${ }^{13} \mathrm{C}$ NMR and Curie-point pyrolysis of the oils and their fractions (S: saturates, A: aromatics, and P: polar compounds), was carried out. The oils employed were prepared from the vacuum residues of two Indonesian crudes (Minas and Duri) and an Arabian mixture (AL/AM) using pentane as solvent. The results of structural analysis suggested that aliphatic portion of Minas and Duri-DAO consisted mainly of straight paraffins, whereas a considerable portion of AL/ AM-DAO consisted of naphthenic structures. The Curie-point pyrolysis at $670^{\circ} \mathrm{C}$ indicated that, irrespective of the oils, the amount of coke from their fractions decreased following the order $\mathrm{P}>\mathrm{A}>\mathrm{S}$. It was also found that the coke formation from each $\mathrm{P}$ or A fraction could be suppressed by adding the saturate fraction, AL/AM-DAO-S, whereas in the case of using Minas- or Duri-DAO-S, no effect of the addition was observed. These results suggest a possibility that unique properties of AL/AM-DAO-S observed may be due to the presence of a considerable amount of active hydrogen in the naphthenic components.
\end{abstract}

\section{Introduction}

Development of further effective utilization techniques for heavy oils is currently one of the most important propositions in petroleum industry. To achieve it, it is generally considered to be basically important to comprehend their structural nature; and a number of methods for their chemical characterization by means of hydrocarbon type analysis by chromatographic separation, instrumental analysis including NMR and MS, and their combinations ${ }^{12}$ 12) have been employed. The structural variation may also affect their reactivity, i.e. cracking properties. Although the relation between their structural and compositional features and catalytic ${ }^{13) \sim 20)}$ and thermal ${ }^{21) ~ 24)}$ cracking characteristics has also been discussed, further fundamental investigations into it appear to be required for more efficient development.

In the light of these considerations, structural analysis of three typical kinds of petroleum deasphalted oils (DAO) by chromatographic separation, followed by ${ }^{1} \mathrm{H}$ and ${ }^{13} \mathrm{C}$ NMR analyses and Curie-point pyrolysis of the oils and their frac-

* To whom correspondence should be addressed. tions, was carried out to provide an insight into the relation between structural characteristics of heavy oils and their thermal cracking behaviors. The results are described herein.

\section{Experimental}

\section{1. Sample Preparation}

The deasphalted oils (DAO) employed were prepared from the atmospheric residues of two Indonesian crudes (Minas and Duri) and an Arabian mixture (AL/AM) (Fig. 1). Kugelrohr distillation of each atmospheric residue $(c a .5 \mathrm{~g})$ at $230^{\circ} \mathrm{C} / 0.5 \mathrm{mmHg}\left(\mathrm{ca} .500^{\circ} \mathrm{C} / 760 \mathrm{mmHg}\right)$ yielded corresponding vacuum gas oil (VGO) and vacuum residue. Benzene $\left(10 \mathrm{~cm}^{3}\right)$ was then added to the residue ( $\mathrm{ca} .3 \mathrm{~g}$ ) and the resulting solution was poured into pentane $\left(200 \mathrm{~cm}^{3}\right)$. After filtration of the mixture to remove the precipitated asphaltene, the solvent was evaporated to give deasphalted oil sample (DAO).

\section{2. Chromatographic Separation}

DAO samples were fractionated by column chromatography. The column used was a glass column tube (inner diameter $20 \mathrm{~mm} \times$ length 600 $\mathrm{mm}$ ), and silica gel (30 g) (Wakogel C 200, Wako Pure Chemical Industries) was activated at $120^{\circ} \mathrm{C}$ 


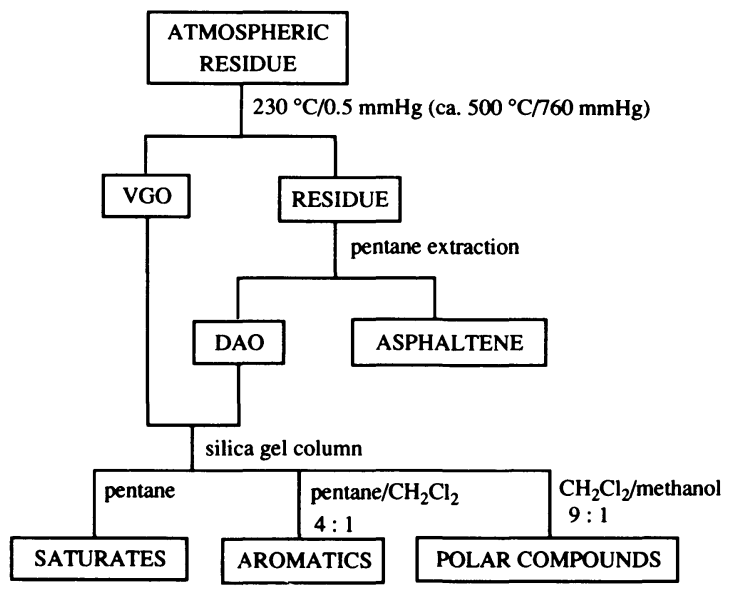

Fig. I Separation Procedure of Atmospheric Residue of Minas, Duri, and AL/AM

for $24 \mathrm{~h}$ under reduced pressure $(1 \mathrm{mmHg})$. About $1 \mathrm{~g}$ of each sample was diluted with pentane ( $c a$. $5 \mathrm{~cm}^{3}$ ) and adsorbed onto the packed material. Successive elution with pentane $\left(90 \mathrm{~cm}^{3}\right)$, pentane $\left(80 \mathrm{~cm}^{3}\right)$, pentane $/ \mathrm{CH}_{2} \mathrm{Cl}_{2}\left(4: 1 \mathrm{v} / \mathrm{v}, 150 \mathrm{~cm}^{3}\right)$, and $\mathrm{CH}_{2} \mathrm{Cl}_{2} /$ methanol $\left(9: 1 \mathrm{v} / \mathrm{v}, 150 \mathrm{~cm}^{3}\right)$ yielded four fractions which were defined as saturates-1 (S-1), saturates-2 (S-2), aromatics (A), and polar compounds $(P)$, respectively. ${ }^{1} \mathrm{H}$ NMR analysis indicated that the $S-1$ fraction essentially consisted of aliphatic compounds, while $S-2$ contained small amounts of aromatic components. The total recovery of each sample was $>95 \%$.

The VGO samples were also separated similarly to facilitate comparison.

\section{3. Instrumental Analysis}

${ }^{1} \mathrm{H}$ and ${ }^{13} \mathrm{C}$ NMR spectra of the DAO and VGO samples and their fractions were recorded on a JEOL JNM-GSX-400 spectrometer for $\mathrm{CDCl}_{3}$ solutions. Elemental analysis of the samples was performed using a Perkin-Elmer $240 \mathrm{CHN}$-corder. GC analysis of the VGO samples was carried out using a Shimadzu GC-8APF gas chromatograph equipped with a CBP-1 capillary column (inner diameter $0.25 \mathrm{~mm} \times$ length $25 \mathrm{~m}$ ).

In the ${ }^{1} \mathrm{H}$ NMR analysis, regions of $0.20-1.05$, 1.05-2.00, 2.00-3.40, and 6.00-9.20 were assigned as $\mathrm{H} \gamma, \mathrm{H} \beta, \mathrm{H} \alpha$, and Har protons, respectively, as reported previously ${ }^{25)}$.

\section{4. Curie-point Pyrolysis}

Curie-point pyrolysis gas chromatographic ( $\mathrm{Py}-$ GC) and mass spectrometric (Py-GC-MS) analyses were carried out by using a Japan Analytical Industry JHP-3 type Curie-point pyrolyzer equipped with a Shimadzu GC-14BPFSC gas chromatograph (CBP-1 capillary column, inner diameter $0.50 \mathrm{~mm} \times$ length $25 \mathrm{~m}$ ) and the same type of
Table 1 Distillation and Solvent Separation Results of Minas, Duri, and AL/AM Atmospheric Residues

\begin{tabular}{lccc}
\hline \multirow{2}{*}{ Fraction } & \multicolumn{3}{c}{ Oil [wt\%] } \\
\cline { 2 - 4 } & Minas & Duri & AL/AM \\
\hline VGO & 49 & 28 & 21 \\
DAO & 45 & 67 & 66 \\
Asphaltene & 6 & 5 & 13 \\
\hline
\end{tabular}

Table 2 Chromatographic Separation Results of VGO and DAO Fractions of Minas, Duri, and AL/AM

\begin{tabular}{|c|c|c|c|c|c|c|}
\hline \multirow{3}{*}{ Fraction } & \multicolumn{6}{|c|}{ Oil [wt $\%]$} \\
\hline & \multicolumn{2}{|c|}{ Minas } & \multicolumn{2}{|c|}{ Duri } & \multicolumn{2}{|c|}{$\mathrm{AL} / \mathrm{AM}$} \\
\hline & VGO & DAO & VGO & DAO & VGO & $\mathrm{DAO}$ \\
\hline Saturates & 83 & 64 & 78 & 47 & 69 & 41 \\
\hline S-1 & & 61 & & 45 & & 28 \\
\hline$S-2$ & & 3 & & 2 & & 13 \\
\hline Aromatics & 15 & 18 & 23 & 23 & 28 & 45 \\
\hline Polar compounds & 2 & 18 & 2 & 30 & 3 & 14 \\
\hline
\end{tabular}

pyrolyzer equipped with a JEOL JMS-DX-303 GC-MS spectrometer, respectively. Acquisition and analysis of MS data were carried out on a JEOL JMA-DA-5100 data station. Each sample ( $c a$. $1 \mathrm{mg}$ ) was pyrolyzed at $670^{\circ} \mathrm{C}$ for $3 \mathrm{~s}$ at a heating rate of $2500 \mathrm{~K} / \mathrm{s}$ under nitrogen stream. The products remained on pyrocell and pyrofoil were defined as tar and coke, respectively ${ }^{26)}$. The weight of volatiles, which were introduced into GC, was calculated using the following equation: weight of volatiles $=$ weight of sample-weight of tar-weight of coke. It is noted that under the conditions, model substrates such as octadecylbenzene and -naphthalene can be pyrolyzed with reasonable conversions ${ }^{26)}$.

\section{Results and Discussion}

\section{1. Composition of Oil Samples}

Table 1 shows the composition of atmospheric residues of Minas, Duri, and AL/AM crude oils determined by distillation and solvent separation. The atmospheric residue of Minas was found to contain a larger amount of VGO than Duri and $\mathrm{AL} / \mathrm{AM}$; the latter two oils had similar compositions.

Table 2 indicates the results of chromatographic separation of the VGO and DAO samples into saturates, aromatics, and polar compounds. Each sample with the exception of the AL/AM-DAO sample which contained a relatively large amount of aromatics gave saturates as the major fraction.

\section{2. Elemental and NMR Analyses}

Table 3 summarizes $\mathrm{H} / \mathrm{C}$ atomic ratio, nitrogen and sulfur contents, $f a$ value (aromaticity index), 
Table 3 Elemental Analysis and ${ }^{1} \mathrm{H}$ NMR Data of VGO and DAO Fractions of Minas, Duri, and AL/AM

\begin{tabular}{|c|c|c|c|c|c|c|c|}
\hline Oil & Fraction & Subfraction ${ }^{a)}$ & $\mathrm{H} / \mathrm{C}^{\mathrm{b})}$ & $\mathrm{N} \%$ b) & $\mathrm{S}^{\mathrm{b})}$ & $f a^{\mathrm{c})}$ & $L p^{\mathrm{d}}$ \\
\hline \multirow{5}{*}{ Minas } & VGO & $S$ & & & & & 0.28 \\
\hline & VGO & A & & & & & 0.46 \\
\hline & DAO & S-1 & 2.07 & -e) & - & & 0.16 \\
\hline & DAO & A & 1.57 & 0.36 & - & 0.32 & 0.29 \\
\hline & DAO & $\mathrm{P}$ & 1.52 & 1.06 & - & 0.34 & 0.26 \\
\hline \multirow[t]{5}{*}{ Duri } & VGO & S & & & & & 0.67 \\
\hline & VGO & A & & & & & 0.59 \\
\hline & DAO & S-1 & 1.99 & - & - & & 0.18 \\
\hline & DAO & A & 1.57 & 0.58 & - & 0.31 & 0.26 \\
\hline & DAO & $\mathrm{P}$ & 1.56 & 1.18 & & 0.32 & 0.26 \\
\hline \multirow[t]{5}{*}{$\mathrm{AL} / \mathrm{AM}$} & VGO & $S$ & & & & & 0.37 \\
\hline & VGO & A & & - & - & & 0.43 \\
\hline & DAO & S-1 & 1.95 & - & - & & 0.32 \\
\hline & DAO & A & $\begin{array}{l}1.57 \\
\end{array}$ & - & 5.23 & 0.33 & 0.43 \\
\hline & DAO & $P$ & 1.57 & 0.82 & 5.23 & 0.33 & 0.40 \\
\hline
\end{tabular}

a) S: saturates, A: aromatics, P: polar compounds. b) By elemental analysis. c) By ${ }^{1} \mathrm{H}$ NMR and elemental analysis. d) $\mathrm{H} \gamma / \mathrm{H} \beta$ ratio in ${ }^{1} \mathrm{H}$ NMR. e) Less than $0.3 \%$.

and $L p$ value (vide infra) for the DAO samples determined by elemental analysis and/or ${ }^{1} \mathrm{H}$ NMR. For the VGO samples, the $L p$ value of saturates and aromatics was determined. The $f a$ value, which indicates the ratio of aromatic carbon number to total carbon number in a given sample, was calculated by the modified Brown-Ladner method reported previously ${ }^{25)}$. The $L p$ value is here defined as $\mathrm{H} \gamma / \mathrm{H} \beta$ ratio in ${ }^{1} \mathrm{H}$ NMR spectrum (see Experimental). This value is an index of average linearity of paraffinic moieties of a given oil; a sample with a higher $L p$ value means a higher composition in isoparaffins, whereas a lower $L p$ value means richer in linear paraffins. It can be seen from Table 3 that saturates-1 of Minas and Duri-DAO have relatively low $L p$ values, 0.16 and 0.18 , suggesting that they contain large amounts of paraffins with higher linearity compared with AL/AM-DAO $(L p=0.32)$, as generally considered for the oils5). It is also worth noting that saturates of Duri-VGO have a considerably higher $L p$ value than that of Duri-DAO, while the values of Minas- and AL/ AM-VGO are similar to those of the corresponding DAO fractions. This may suggest that the paraffin structure of Duri crude along with its boiling range is not continuous; consequently, the VGO-S fractions have been subjected to GC analysis. The chromatograms (Fig. 2) were markedly different in their patterns. In consistent with the $L p$ value, Minas-VGO-S showed a series of regular peaks which were due to the linear paraffins in a range of about $\mathrm{C}_{15}-\mathrm{C}_{30}$. By contrast, the chromatogram of Duri-VGO-S was rather complex. This may be due to the higher content of isoparaffins and/or naphthenic compounds. AL/AM-VGO-S showed a chromatogram like that of a combination of Minas-VGO-S and Duri-DAO-S.

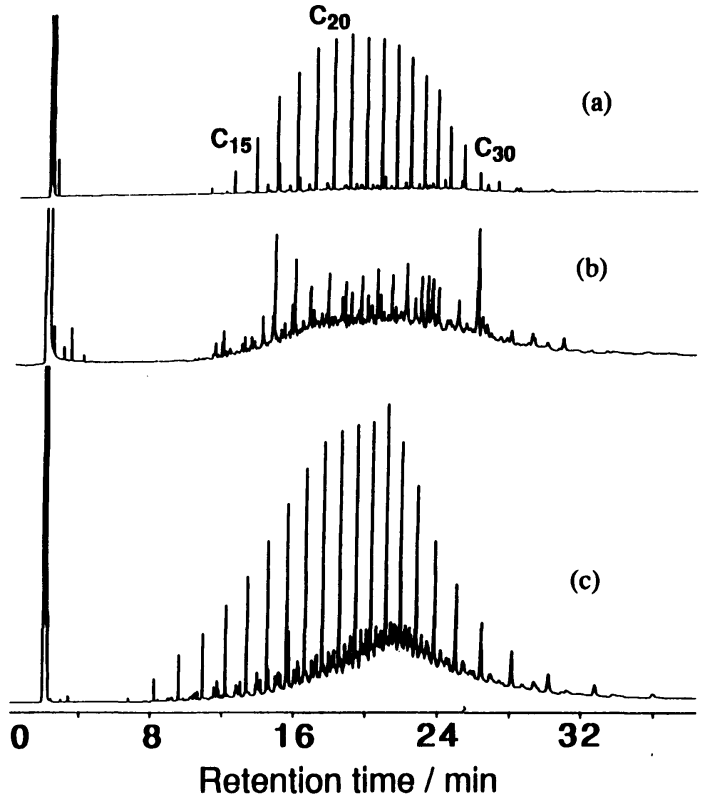

Fig. 2 GC Chromatograms of VGO-Saturates Fractions of (a) Minas, (b) Duri, and (c) AL/AM

Aromatics and polar compounds fractions of the DAO samples appeared to have similar $f a$ values in the range of 0.31-0.34, irrespective of the crudes, suggesting that these fractions have similar aromatization degrees.

Figure 3 shows the ${ }^{13} \mathrm{C}$ NMR spectra of Minas-DAO-S-1 and AL/AM-DAO-S-1 obtained by using the DEPT $\left(135^{\circ}\right)$ method, where the upward peaks are due to methyl and methine carbons and the downward peaks are due to methylene carbons. The peaks around $14 \mathrm{ppm}$ are assignable to the terminal methyl carbons in parafinic compounds ${ }^{27}$. Those peaks around 23, 29-30, and 32 ppm can be assignable to the inner 


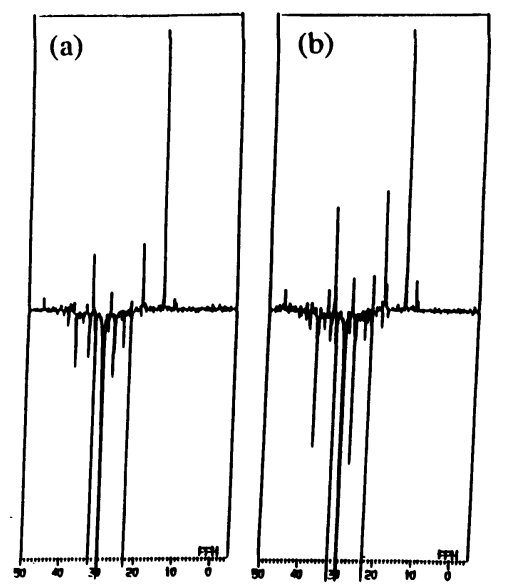

Fig. 3 DEPT $\left(135^{\circ}\right){ }^{13} \mathrm{C}$ NMR Spectra of DAO-Saturates-l Factions of (a) Minas and (b) AL/AM

Table 4 Curie-point Pyrolysis Data of Minas-, Duri-, and $\mathrm{AL} / \mathrm{AM}-\mathrm{DAO}$ and Their Fractions $\mathrm{s}^{\mathrm{a}}$

\begin{tabular}{ccccc}
\hline \multirow{2}{*}{ Oil } & \multirow{2}{*}{ Fraction $^{\text {b) }}$} & \multicolumn{3}{c}{ Products [wt\%] } \\
\cline { 3 - 5 } & & Volatile & Tar & Coke \\
\hline Minas & & 72 & 19 & 9 \\
& S-l & 78 & 20 & 2 \\
& $\mathrm{~A}$ & 54 & 40 & 6 \\
Duri & $\mathrm{P}$ & 45 & 33 & 22 \\
& & 59 & 26 & 15 \\
& S-1 & 63 & 29 & 8 \\
AL/AM & $\mathrm{A}$ & 57 & 29 & 15 \\
& $\mathrm{P}$ & 46 & 25 & 29 \\
& & 54 & 43 & 3 \\
& S-1 & 69 & 30 & 1 \\
& $\mathrm{~A}$ & 35 & 51 & 14 \\
& $\mathrm{P}$ & 44 & 31 & 25 \\
\hline
\end{tabular}

a) Pyrolysis conditions: $670^{\circ} \mathrm{C}(3 \mathrm{~s})$. b) S-l: saturates-1, A: aromatics, $\mathrm{P}$ : polar compounds.

methylene carbons in linear paraffins at $\alpha,>\gamma$, and $\beta$ positions from the terminal methyl carbon, respectively ${ }^{28)}$. Thus, in harmony with ${ }^{1} \mathrm{H}$ NMR, Minas-DAO-S-1 may be considered to contain linear paraffins as major components. It is noted that Duri-DAO-S-1 showed a spectrum similar to that of Minas-DAO-S-1. The methylene peaks around 27 and $37 \mathrm{ppm}$ and the methine peak around $33 \mathrm{ppm}$ may suggest the presence of naphthenic compounds along with isoparaffins ${ }^{28}$. These peaks are observed as significantly strong ones in the spectrum of AL/AM-DAO-S-1, suggesting that the fraction contains a considerable amount of naphthenic compounds. This may be the major reason that the $L p$ value of AL/AM-DAO-S-l is larger than that of Minasand of Duri-DAO-S-1.

\section{3. Curie-point Pyrolysis}

The results of Curie-point pyrolysis of the deasphalted oils and their fractions at $670^{\circ} \mathrm{C}$ are

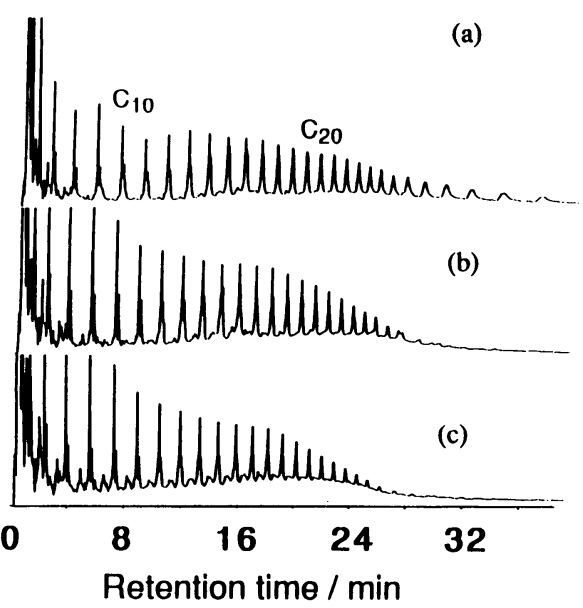

Fig. 4 Curie-point Pyrolysis-GC Charts of DAO-Saturates-l Fractions of (a) Minas, (b) Duri, and (c) $\mathrm{AL} / \mathrm{AM}$

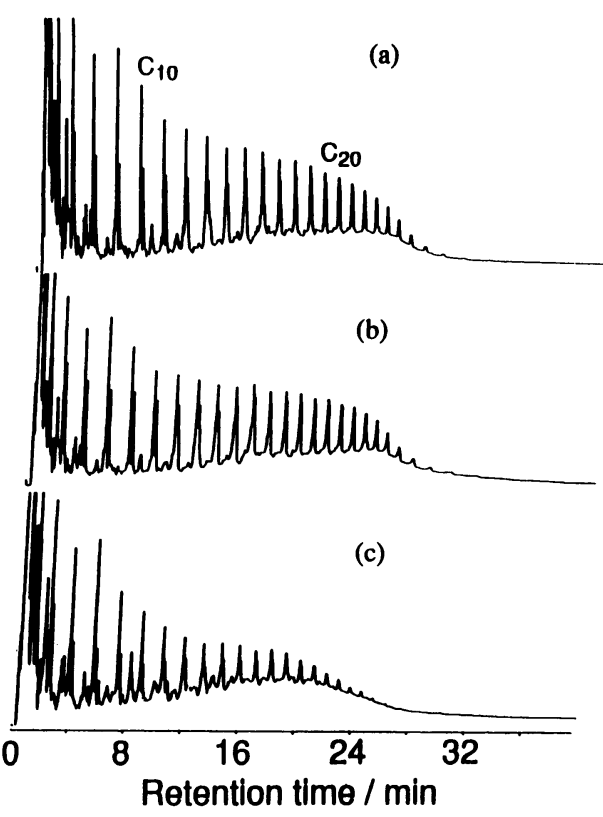

Fig. 5 Curie-point Pyrolysis GC Charts of DAO-Aromatics Fractions of (a) Minas, (b) Duri, and (c) $\mathrm{AL} / \mathrm{AM}$

presented in Table 4 in which the product distribution is also presented. Figures $\mathbf{4}$ and $\mathbf{5}$ show the pyrograms of saturates-1 and aromatics, i.e. chromatograms of volatile matters. It was confirmed that each DAO sample gave almost no peaks when it was directly injected to GC, suggesting that the peaks observed in the pyrograms were attributable to the pyrolytic products. The periodic couple peaks in each pyrogram were attributable to $n$-alkane and $n$-alkene pairs by Py-GC-MS. It is noted that the product 
distribution in the pyrograms does not directly correlate with the chain length composition in the samples, since a long chain alkane undergoes pyrolysis to give a mixture of various alkanes and alkenes under the same conditions ${ }^{26)}$. However, it can be seen that the existence of compounds at least up to $\mathrm{C}_{30}$ can be confirmed. Minas- and DuriDAO-S-1 gave rather linear base lines in their pyrograms (Fig. 4). This suggests that the fractions contain long $n$-paraffins as predominant components, as indicated by their ${ }^{1} \mathrm{H}$ and ${ }^{13} \mathrm{C}$ NMR spectra. On the other hand, AL/AM-DAO-S-1 gave a relatively broad base line and there was a considerable number of peaks between the $n$ alkane/ $n$-alkene pair peaks. Based on the results of its ${ }^{1} \mathrm{H}$ and ${ }^{13} \mathrm{C}$ NMR analyses, the peaks and the base line may be due to the various isomers of naphthenic compounds as well as to isoparaffins. In contrast to their saturates, Minas- and DuriDAO-A showed broad base lines. This may be attributable to the formation of various alkyl aromatic compounds by pyrolysis.

The amount of coke formed in the pyrolysis of the whole DAO samples decreased in the order Duri $(15 \%)>$ Minas $(9 \%)>$ AL/AM $(3 \%)$ (Table 4). Irrespective of the original crudes, the coke yield from their fractions decreased following the order $\mathrm{P}(22-29 \%)>\mathrm{A}(6-15 \%)>\mathrm{S}(1-8 \%)$. It was of quite interest to note that pyrolysis of the whole AL/ AM-DAO sample produced a smaller yield of coke (3\%) than was expected from the content of the fractions and their coking properties, whereas Minas- and Duri-DAO gave rather normal yields of coke. This may imply that $\mathrm{S}$ fraction, AL/ AM-DAO-S-1, suppresses the coke formation from its $\mathrm{A}$ and $\mathrm{P}$ fractions. Consequently, the pyrolysis of $\mathrm{A}$ and $\mathrm{P}$ fractions of Minas- and Duri-DAO was conducted by mixing the same amount of AL/AM-DAO-S-1. The results are shown in Table 5. It can be seen that only a negligible amount of coke $(<1 \%)$ was formed from Minas-DAO-A, and the coke formation from Minas-DAO-P was significantly suppressed. The $\mathrm{P}$ and A fractions of Duri-DAO similarly yielded smaller amounts of coke in the presence of AL/AM-DAO-S-1.

The above pyrolysis data together with the results of structural analyses lead us to deduce that one of the major factors of the unique properties of AL/AM-DAO-S-1, suppressing coke formation, can be attributed to the presence of considerable amounts of naphthenic components. In turn, the difference between Minas- and Duri-DAO-S and $\mathrm{AL} / \mathrm{AM}-\mathrm{DAO}-\mathrm{S}$ in their coking properties could also be interpreted in terms of the donating ability of hydrogen. Naphthenic compounds may re-
Table 5 Curie-point Pyrolysis Data of Mixed Samples of DAO Fractions $s^{\text {a) }}$

\begin{tabular}{cccc}
\hline \multirow{2}{*}{ Mixture sample } & \multicolumn{3}{c}{ Products [wt\%] } \\
\cline { 2 - 4 } & Volatile & Tar & Coke \\
\hline AL/AM-DAO-S-1+Minas-DAO-A & 64 & 36 & $<1$ \\
AL/AM-DAO-S-1+Minas-DAO-P & 63 & 31 & 6 \\
AL/AM-DAO-S-1+Duri-DAO-A & 69 & 27 & 4 \\
AL/AM-DAO-S-1+Duri-DAO-P & 46 & 46 & 8 \\
\hline a) Pyrolysis conditions: $670^{\circ} \mathrm{C}(3 \mathrm{~s})$. & b) Sample ratio: $1: 1$
\end{tabular}

(wt/wt). S-l: saturates-1, A: aromatics, P: polar compounds.

lease hydrogen more easily than $n$-paraffins accompanied by aromatization to suppress coke formation.

\section{Conclusion}

In the present study, structural analysis of three kinds of deasphalted oils (DAO) derived from two Indonesian crudes (Minas and Duri) and an Arabian mixture (AL/AM) and Curie-point pyrolysis of the oils and their fractions (S: saturates, A: aromatics, and P: polar compounds) were carried out to provide an insight into the relation between structural characteristics of petroleum heavy oils and their thermal cracking properties. The results obtained are as follows:

1) Minas- and Duri-DAO contain saturates (S) as their major component, whereas a relatively large amount of aromatics (A) is found in $\mathrm{AL}$ / AM-DAO.

2) The Minas- and Duri-DAO-S fractions consist mainly of long linear paraffins, as has been generally considered, while considerable amounts of naphthenic compounds are found in AL/AMDAO-S.

3) In the Curie-point pyrolysis of the whole DAO samples, the amount of coke formed decreases in the order Duri $>$ Minas $>$ AL/AM. Irrespective of the original crudes, the coke yield from the fractions decreased as follows $\mathrm{P}>\mathrm{A}>\mathrm{S}$.

4) The major reason as to why $\mathrm{AL} / \mathrm{AM}-\mathrm{DAO}$ produces a remarkably small amount of coke can be attributed to the existence of a considerable amount of naphthenic compounds which may donate hydrogen more easily than straight paraffins. This concept may be supported by the fact that coke formation in the pyrolysis of $\mathrm{A}$ and $\mathrm{P}$ fractions of Minas- and Duri-DAO is markedly suppressed by mixing them with AL/AM-DAO-S. To ascertain this consideration, futher studies using model compounds as hydrogen donors will be carried out. 


\section{Acknowledgment}

This work has been carried out as a research project of The Japan Petroleum Institute commissioned by the Petroleum Energy Center with the subsidy of the Ministry of International Trade and Industry.

We thank Taiyo Oil Co., Ltd. for Minas and Duri crudes and Nippon Oil Co., Ltd. for the Arabian mixture.

\section{References}

1) Asaoka, S., Nakata, S., Nenryo Kyokaishi, 65, 783 (1986).

2) Yamamoto, Y., Sekiyu Gakkaishi, 29, (11), 15 (1986)

3) O'Donnell, D.J., Sigle, S.O., Berlin, K.D., Sturm, G.P., Vogh, J.W., Fuel, 59, 166 (1980).

4) Boduszynski, M.M., Energy Fuels, 2, 597 (1988).

5) Honjo, I., Ohta, K., Kamiya, K., Kubo, J., Sakai, K., Sekiyu Gakkaishi, 32, (4), 199 (1989).

6) Ronningsen, H.P., Skjevrak, I., Energy Fuels, 4, 608 (1990).

7) Ueda, K., Matsui, H., Malhotra, R., Nomura, M., Sekiyu Gakkaishi, 34, (1), 62 (1991).

8) Chasey, K.L., Aczel, T., Energy Fuels, 5, 386 (1991).

9) Sugimoto, Y., Miki, Y., Niwa, Y., Tunnukij, K., Yamadaya, S., Sekiyu Gakkaishi, 35, (4), 339 (1992).

10) Sugimoto, Y., Miki, Y., Niwa, Y., Tunnukij, K., Yamadaya, S., Sekiyu Gakkaishi, 35, (4), 349 (1992).

11) Trauth, D.M., Stark, S.M., Petti, T.F., Neurock, M., Klein, M.T., Energy Fuels, 8, 576 (1994).

12) Sergeant, D.G., Stubington, J.F., Barret, D., Do,
P.T.D.H., Raval, K.A., Fuel, 74, 51 (1995).

13) Ozaki, H., Suzuka, T., Nenryo Kyokaishi, 65, 370 (1986).

14) Kawakatsu, T., Nenryo Kyokaishi, 65, 1043 (1986).

15) Nita, K., Itoh, Y., Nenryo Kyokaishi, 66, 73 (1987).

16) Maki, H., Kawaguchi, M., Miura, M., Nomura, M. Matsui, H., Okabayashi, N., Kaneko, M., Sekiyu Gakkaishi, 30, (1), 47 (1988).

17) Nomura, M., Maki, H., Miura, M., Sekiyu Gakkaishi, 31, (6), 473 (1988)

18) Seimiya, K., Hashimoto, M., Suzuki, S., Kameyama, M., Noguchi, Y., Nita, K., Sekiyu Gakkaishi, 33, (1), 52 (1990).

19) Fukase, S., Maruyama, G., Sekiyu Gakkaishi, 37, (6), 603 (1994).

20) Ternan, M., Rahimi, P.M., Clugsron, D.M., Dettman, H.D., Energy Fuels, 8, 518 (1994).

21) Matsuo, I., Yoshida, S., Nenryo Kyokaishi, 65, 860 (1986).

22) Wakabayashi, T., Koguchi, K., Nakamura, E., Sekiyu Gakkaishi, 32, (6), 286 (1989)

23) Sebor, G., Blazek, J., Lederer, J., Ricanek, M., Novak, V., Fuel, 71, 1231 (1992).

24) Udaja, P., Duffy, G.J., Fookes, C.J.R., Chensee, M.D., Fuel, 72, 845 (1993).

25) Kanda, N., Itoh, H., Yokoyama, S., Ouchi, K., Fuel, 57, 676 (1978).

26) Murata, S., Mori, T., Murakami, A., Nomura, M., Energy Fuels, 9, 119 (1995).

27) Silverstein, R.M., Bassler, G.C., Morrill, T.C., "Spectroscopic Identification of Organic Compounds," 5th ed., Wiley, (1991).

28) Hayamizu, K., Yamamoto, O., "13C NMR Spectra of Polycyclic Aromatic Compounds,' Jpn. Ind. Assoc. Tokyo (1982). 
要 旨

\title{
脱れき油の構造分析およびその熱分解特性
}

\author{
Wega Trisunaryanti, 三浦 雅博, 野村 正勝
}

大阪大学工学部応用化学科, 565 大阪府吹田市山田丘 2-1

\begin{abstract}
インドネシア産ミナスおよびデュリ原油ならびにアラビアン ミックス ( $\mathrm{AL} / \mathrm{AM})$ の 3 種の原油から得た脱れき油（DAO） を対象に, カラムクロマト分離と NMR 分析により化学構造 を解析するとともに, それらの分解特性をキュリーポイント熱 分解法により評価・検討した。各 DAO のクロマト分離から, ミナスでは飽和化合物留分が, AL/AM では芳香族化合物留分 が相対的に多いこと，およびデュリはその中間であることがわ かった。また, 各飽和化合物留分の NMR 分析より, ミナス, デュリでは直鎖パラフィン構造が主体であるのに対し,
\end{abstract} $\mathrm{AL} / \mathrm{AM}$ ではシクロパラフィン構造が相対的に多いことが明ら
かになった。一方，各 DAO ならびにそれらのフラクションの 熱分解では, AL/AM-DAO の飽和化合物留分にコーク生成を 抑制する作用があることを示唆する結果が得られた。またここ のことは，AL/AM-DAO の飽和化合物留分をミナスおよび デュリDAO の芳香族化合物ならびに極性化合物留分とを混合 すると, それぞれの留分からのコーク生成量が顕著に減少する という実験事実からも支持された。これらの構造分析ならびに 熱分解結果より, AL/AM-DAO に含まれるシクロパラフィン 構造がコーク生成の抑制に有効である可能性が示唆される。

\section{Keywords}

Heavy oil, Coking, Deasphalted oil, Structural characterization, Chromatographic separation,

Curie-point pyrolysis 